\title{
Base temperature as a function of genotype: a foundation for modeling phenology of temperate fruit species
}

\section{Temperatura-base inferior em relação ao genótipo: fundamento para modelagem da fenologia em espécies frutíferas de clima temperado}

\author{
Rafael Anzanello ${ }^{1 *}$; Luiz Antonio Biasi²
}

\begin{abstract}
To complete each phase of the growing season, plants must accumulate thermal time at lower base temperature $(\mathrm{Tb})$. Little information exists on $\mathrm{Tb}$ variation between either fruit species or cultivars of the same species. We therefore aimed to determine the lower base temperature for contrasting genotypes in precocity of peach, plum, grape, pear, and kiwi. Twigs $25-35 \mathrm{~cm}$ long for the following cultivars: peach, Tropic Beauty (TB) and Eragil (ER); plum, Gulf Blaze (GB) and Letícia (LE); grape, Chardonnay (CH) and Cabernet Sauvignon (CS); pear, Smith (SM) and Packham's (PA); and kiwi, Golden King (GK) and Hayward (HA) were collected in orchards in Veranópolis, RS Estate, on 06/13/2014, with $0 \mathrm{~h}$ at temperatures $\leq 7.2^{\circ} \mathrm{C}$ (chilling hours; $H_{C}$ ) in the field. Intact twigs packed in black plastic film were subjected to $1,008 H_{C}$ at $0^{\circ} \mathrm{C}$ in incubators to overcome dormancy and then transferred to temperatures of $2,4,6,8,10$, and $12^{\circ} \mathrm{C}$ on single-node cuttings planted in phenolic foam to define effective heat temperature for the genotypes. Over $110 \mathrm{~d}$, budburst of the buds was evaluated in 2-3-d intervals in the green-tip stage. The resulting inverse data of number of days to budburst (1/days to budburst) was inserted into regression curves to estimate $\mathrm{Tb}$ for each genotype. Historical phonological series comprised of 10 years for the analyzed cultivars and meteorological data of the cultivation sites were used to determine thermal time (degree-days) for the fruit trees during the growing season, considering different phenological phases. Temperate fruit species exhibited different $\mathrm{Tb}$ behaviors: $\mathrm{Tb}$ was lower for early cultivars ( $\mathrm{TB}$ and $\mathrm{GB}=2.2^{\circ} \mathrm{C} ; \mathrm{CH}=2.1^{\circ} \mathrm{C}$; $\mathrm{SM}=4.4^{\circ} \mathrm{C} ; \mathrm{GK}=4.3^{\circ} \mathrm{C}$ ) and higher for late cultivars $\left(\mathrm{ER}=6.3^{\circ} \mathrm{C} ; \mathrm{LE}=6.2^{\circ} \mathrm{C} ; \mathrm{CS}=4.3^{\circ} \mathrm{C}\right.$; $\mathrm{HA}$ and $\left.\mathrm{PA}=8.2^{\circ} \mathrm{C}\right)$ for all cultures. The $\mathrm{Tb} f$ fruit cultivars related directly with genotype chilling requirements: the higher the chilling requirement, the higher the $\mathrm{Tb}$ of the cultivar. Cultivars of the same fruit species yielded a sum of degree-days almost equal to finalize the growing season, regardless of the degree of precocity $(\mathrm{TB}=1720 ; \mathrm{ER}=1801$; $\mathrm{GB}=1680 ; \mathrm{LE}=1718 ; \mathrm{CH}=2310 ; \mathrm{CS}=2369 ; \mathrm{SM}=2096 ; \mathrm{PA}=2003 \mathrm{GD} ; \mathrm{GK}=2775 ; \mathrm{HA}=2691$ ). Regarding phenological phases, $82 \%$ of the assessed cases responded more to thermal time (degree-days) than to chronological time (d) to complete phenological steps. Differences in Tb between genotypes are a relevant factor for improving the accuracy and applicability of phenology models in agriculture.
\end{abstract}

Key words: Growing season. Dormancy. Thermal sum. Degree-days.

\section{Resumo}

Para completar cada subperíodo do ciclo vegetativo, as plantas necessitam de uma soma térmica acumulada a partir da temperatura-base inferior $(\mathrm{Tb})$. Há pouca informação que mostre variação da $\mathrm{Tb}$, considerando espécies e cultivares de uma mesma espécie frutífera. $\mathrm{O}$ objetivo deste estudo foi

${ }^{1}$ Eng $^{\mathrm{o}}$ Agr $^{\circ}$, Dr., Fundação Estadual de Pesquisa Agropecuária, FEPAGRO Serra, Veranópolis, RS, Brasil. E-mail: rafaelanzanello@fepagro.rs.gov.br

2 Eng ${ }^{\circ}$ Agr $^{\circ}$, Prof. Dr., Faculdade de Agronomia, Universidade Federal do Paraná, UFPR, Curitiba, PR, Brasil. E-mail: biasi@ufpr.br Author for correspondence 
determinar a temperatura-base inferior para genótipos contrastantes em precocidade de pessegueiro, ameixeira, videira, pereira e quivizeiro. Estacas com $25-35 \mathrm{~cm}$ de comprimento das cultivares de pessegueiro 'Tropic Beauty' (TB) e 'Eragil' (ER), de ameixeira 'Gulf Blaze' (GB) e 'Letícia' (LE); de videira 'Chardonnay' (CH) e 'Cabernet Sauvignon' (CS), de pereira 'Smith' (SM) e 'Packham's' (PA) e de quivizeiro 'Golden King' (GK) e 'Hayward' (HA) foram coletadas em pomares localizados no município de Veranópolis, RS, em 13/06/2014, com zero horas de frio $\leq 7,2^{\circ} \mathrm{C}$ (HF) a campo. As estacas intactas foram submetidas a $0^{\circ} \mathrm{C}$ por $1.008 \mathrm{HF}$, em câmaras incubadoras para a superação da dormência, embaladas em filme plástico preto. Na sequência, foram transferidas para as temperaturas de $2,4,6,8,10$ e $12^{\circ} \mathrm{C}$, em estacas de nós-isolados, plantadas em espuma fenólica. Durante 110 dias, as gemas foram avaliadas a cada 2-3 dias quanto à brotação, no estádio de ponta verde, e os dados do inverso do número de dias para brotação (1/dias para brotação) inseridos em curvas de regressão para estimativa da Tb para cada genótipo. Séries históricas de fenologia de 10 anos das cultivares analisadas e dados meteorológicos dos locais de cultivo foram utilizados para o cálculo da soma térmica (grausdia) das frutíferas durante o ciclo vegetativo, considerando diferentes subperíodos fenológicos. A Tb se diferenciou entre as espécies frutíferas de clima temperado. A Tb foi menor para cultivares precoces (TB e $\left.\mathrm{GB}=2,2^{\circ} \mathrm{C} ; \mathrm{CH}=2,1^{\circ} \mathrm{C} ; \mathrm{SM}=4,4^{\circ} \mathrm{C} ; \mathrm{GK}=4,3^{\circ} \mathrm{C}\right)$ e maior para cultivares tardias $\left(\mathrm{ER}=6,3^{\circ} \mathrm{C} ; \mathrm{LE}=\right.$ $6,2^{\circ} \mathrm{C} ; \mathrm{CS}=4,3^{\circ} \mathrm{C} ; \mathrm{PA}$ e $\mathrm{HA}=8,2^{\circ} \mathrm{C}$ ), para todas as culturas. A Tb das cultivares frutíferas se relacionou diretamente com a necessidade de frio do genótipo, sendo quanto maior a exigência em frio hibernal, maior a $\mathrm{Tb}$ da cultivar. Cultivares pertencentes a uma mesma espécie frutífera apresentaram soma de graus-dia quase igual para finalizar o ciclo vegetativo, independente do grau de precocidade $(\mathrm{TB}=$ 1720; $\mathrm{ER}=1801 ; \mathrm{GB}=1680 ; \mathrm{LE}=1718 ; \mathrm{CH}=2310 ; \mathrm{CS}=2369 ; \mathrm{SM}=2096 ; \mathrm{PA}=2003 \mathrm{GD} ; \mathrm{GK}=$ 2775; HA $=2691$ ). Os subperíodos fenológicos das frutíferas, em $82 \%$ dos casos, responderam mais ao tempo térmico (graus-dia) do que ao tempo cronológico (dias) para completar as etapas fenológicas. A diferenciação da Tb entre genótipos é um importante fator a ser considerado para ajustes de modelos de fenologia, como fundamento para melhoria da sua precisão e aplicabilidade na agricultura.

Palavras-chave: Ciclo vegetativo. Dormência. Soma térmica. Graus-dia.

\section{Introduction}

Thermal conditions have a direct effect on plant growth and development. High temperatures accelerate plant metabolism, whereas low temperatures reduce plant growth and prolong their cycle. In regions with pronounced annual thermal oscillation, such as southern Brazil, temperate fruit species enter dormancy in the fall/winter, and then begin a growing season in the spring, when air temperatures increase (BERGAMASCHI, 2007).

During the vegetative period, plants respond to the accumulation of air temperature, or thermal time, measured in in degree-days (SOUZA et al., 2011a; CARDOSO et al., 2012). This model represents an integration of the effective temperatures for plant growth, fixed between two thermal thresholds: the base temperature $(\mathrm{Tb})$ and the ceiling temperature (Tc) (BERGAMASCHI, 2007). The lower threshold $(\mathrm{Tb})$ corresponds to the temperature at which plant metabolism is activated, and the upper threshold (Tc) corresponds to the maximum temperature at which the plant can perform photosynthesis. Although the degree-day model meets both thermal thresholds ( $\mathrm{Tb}$ and $\mathrm{Tc}$ ), ignoring periods where temperature is below $\mathrm{Tb}$ and above Tc, most models only consider the lower limit $(\mathrm{Tb})$ in calculating thermal time when applied to fruit trees under the conditions of southern Brazil (ARNOLD, 1959; VILLA NOVA et al., 1972). This is because maximum daily temperatures in southern Brazil rarely exceed the Tc of temperate fruit trees (LAZZARI, 2011), thus remaining below the upper thermal limit of photosynthesis.

The concept of thermal time, or degree-day, obtained from the base temperature of the crops, reduces discrepancies in plant cycle observations under different thermal regimes compared to calendar days (DAY et al., 2008). The duration of the phenological stages and cycle varies between years and sites for a given species or variety, depending on the environmental thermal conditions. 
In contrast, the degree-day requirement tends to be uniform for the same genotype in different thermal environments. This allows characterization of plant growth patterns across different sites and periods, unless other factors interfere (BERGAMASCHI, 2007). The degree-day sum that plants require to complete a portion of or an entire cycle has been used to characterize phenological phases and/or plant production (SCHWARTZ, 2003). Because this parameter incorporates the thermal demand of crops, it allows early prediction of the approximate phenological dates in a region and contributes to planning and management of agricultural activities (MILLER et al., 2001).

Temperate fruit trees require cold to overcome dormancy in the fall-winter; afterward, the buds enter a phase that requires heat (ANZANELLO, 2012). Miller et al. (2001) describe the calculation of total heat requirement based upon temperatures experienced above the $\mathrm{Tb}$ for each phase of plant development. The date at which an organism begins to respond to accumulated heat is known as "biofix." In the case of temperate fruit trees, this date is when endodormancy (dormancy controlled by cold) ends. In the next phase, ecodormancy, the plants have not begun the budburst stage, but are collecting the necessary heat to achieve it. The "biofix" date can also be the first date of a phase (e.g., flowering to ripening), no matter how much heat was accumulated during the previous phases (LAZZARI, 2011).

The degree-day models based on $\mathrm{Tb}$ applied to fruit trees have some limitations. Typically, estimating degree-days for temperate fruit trees is based upon a single $\mathrm{Tb}$ value $-4.5^{\circ} \mathrm{C}$, from Richardson et al. (1975). However, Rodríguez (1995) and Marra et al. (2002) found $\mathrm{Tb}$ to be between 5 and $7^{\circ} \mathrm{C}$ for stone fruit trees. Hidalgo (1980), Morley-Bunker and Salinger (1987), Pedro Junior et al. (1994), and Nagata et al. (2000) determined a minimum basal temperature of $10^{\circ} \mathrm{C}$ for grape and kiwi crops. Spiegel-Roy and Alston (1979) found a basal temperature of $4.5^{\circ} \mathrm{C}$ for pear trees. According to Scarpare (2007), it is important to consider specificity, both between species and between cultivars of the same fruit species, in selecting a $\mathrm{Tb}$ parameter for the best-fit phenology model. According to Berlato and Sutilli (1976), a flaw in some mathematical models is that they do not discriminate the $\mathrm{Tb}$ of each species or genotype (early-, intermediate-, or late-maturing cultivar) as a basis for accurate modeling of plant phenology.

Putti et al. (2003) and Anzanello (2012) report possible differences in $\mathrm{Tb}$ among cultivars within a single fruit species. They found that apple cultivars contrasting in thermal requirement during dormancy show different intervals of effective cold temperatures - higher $\left(3\right.$ to $12^{\circ} \mathrm{C}$ ) for genotypes with low winter chilling requirements, and lower (3 to $6^{\circ} \mathrm{C}$ ) for those with high chilling requirements. These results support the idea that the $\mathrm{Tb}$, from which plants compute heat, differs between cultivars with contrasting thermal requirements. Such a distinction would result in different heat requirements over the growing season to achieve each phenological phase among genotypes, compared to the undifferentiated thermal times calculated using a standard $\mathrm{Tb}$.

The definition of $\mathrm{Tb}$, applied to fruit tree species, is also limited by not considering the plants' biological responses. This parameter should be determined experimentally, considering the plants' biological status, rather than referring exclusively to statistical modeling, as in past research by Richardson et al. (1975), Spiegel-Roy and Alston (1979), Hidalgo (1980), Morley-Bunker and Salinger (1987), Pedro Junior et al. (1994), Rodríguez (1995), Nagata et al. (2000), Marra et al. (2002), Green (2007), and Souza et al. (2011b). In those studies, $\mathrm{Tb}$ was based on an estimate, not an actual observation obtained experimentally; i.e., $\mathrm{Tb}$ was defined by evaluating the least standard deviation that a temperature, selected a priori, confers to the thermal time of a collection of data from past years/experiments (ARNOLD, 1959). Using biological methods instead not only reflects the plants' intrinsic conditions, but also allows for 
isolating environmental factors, such as the effect of air temperature on plants (ANZANELLO et al., 2014).

This study aimed to determine $\mathrm{Tb}$ for genotypes of peach, plum, grape, pear, and kiwi with different degrees of phenological precocity.

\section{Materials and Methods}

\section{Lower Tb of the temperate fruit trees}

Cuttings from early (EC) and late cultivars (LC) of temperate fruit tree species were collected from the year's new growth during winter 2014. The following species and cultivars were selected: peach (EC -Tropic Beauty and LC -Eragil), plum (EC -Gulf Blaze and LC -Letícia), grape (EC Chardonnay and LC -Cabernet Sauvignon), pear (EC -Smith and LC -Packham's), and kiwi (EC -Golden King and LC -Hayward). The peach, plum, pear, and kiwi cultivars were collected at experimental orchards belonging to the State Foundation of Agricultural Research-Serra (FEPAGRO Serra), in Veranópolis, RS, Brazil, and the grape cultivars were collected at commercial vineyards within the same municipality.

The cuttings sampled were 25-35 cm long, exhibiting, on average, six buds for grape and kiwi cultivars, eight for pear cultivars, and 30 for peach and plum cultivars. The sampling was performed on June 13, 2014, for all of the cultivars, with 0 $\mathrm{h}$ of temperature $\leq 7.2^{\circ} \mathrm{C}$ (chilling hours $-\mathrm{H}_{\mathrm{C}}$ ) in the field. In selecting the material for sampling, bud maturity (identified by the presence of tightly closed buds), health, and vigor of the cuttings were considered, prioritizing those with intermediate growth.

After the cuttings were collected from the field, they were wrapped in bundles, moistened, and stored in plastic bags until processing. Next, the material was sterilized and cleaned by a sequence comprising 70\% ethanol for 45-60 seconds, $2.5 \%$ sodium hypochlorite for 20 minutes, and three rinses with distilled water. After cleaning, the cuttings were shade-dried for approximately 30 minutes (ANZANELLO et al., 2014).

The intact cuttings were organized into bundles of 20-25 units each, packed into black polyethylene plastic film, and placed in Eletrolab EL202 climatic incubating chambers. They were subjected to a prolonged cold interval $\left(1,008 H_{C}\right.$ at $\left.0^{\circ} \mathrm{C}\right)$, without photoperiod, to overcome endodormancy.

After the cold interval, the cuttings were processed for single-node cultures (ANZANELLO et al., 2014). The cuttings were fragmented into 6-cm-long segments containing only one lateral bud in the upper portion. Next, the cuttings were planted in wet phenolic foam placed inside plastic pots. To determine the effective heat temperature, the pots with the cuttings were subjected to six temperature treatments $\left(2,4,6,8,10\right.$, and $\left.12^{\circ} \mathrm{C}\right)$ in incubating chambers for $110 \mathrm{~d}$, without photoperiod. Each heat treatment had three replicates (three pots with ten cuttings). The incubating chambers were subdivided into three shelves, one replicate per shelf, in order to control for differences in air circulation inside the incubating chambers.

Throughout the evaluation period (110 d), the buds were observed every 2-3 d, noting their budburst date at the green tip stage (CARVALHO et al., 2010). Using the budburst data, the variables 'mean budburst time', which represented the mean number of days between beginning the experiment and detecting the green tip stage, and 'final budburst rate', which represented the percentage of cuttings with buds that reached the green tip stage, were calculated (CARVALHO; BIASI, 2012). The flowering buds of the peach and plum plants were not evaluated; only the vegetative bud (central bud) was analyzed to standardize with the other crops.

The cuttings were irrigated at a rate of approximately $20 \mathrm{~mL}$ of water per pot every 48-72 $h$ inside the incubating chambers. Water relocation was sufficient to saturate the phenolic foam while avoiding free water accumulation in the pots. 
Throughout the experiment, development of diseases inside the incubating chambers was prevented by using systemic (pyrimethanil and tebuconazole) and contact (iprodione and captan) pesticides. All agrochemicals were added in 1.52.0-mL L $\mathrm{m}^{-1}$ doses, except tebuconazole, which was added at a level of $1.0 \mathrm{~mL} \mathrm{~L}^{-1}$. The agrochemicals were applied every 14-21 d, alternating systemic and contact products.

\section{Phenological databases}

A 10-year phenological database of the cultivars listed was organized, combined with corresponding meteorological data, to quantify the thermal time (degree-days) during the fruit trees' growing seasons. The $\mathrm{Tb}$ value determined for each genotype was used to calculate the thermal time. The phenological database comprised the following data: budburst ( $50 \%$ bud burst), onset of flowering (10\% open flowers), end of flowering (100\% fallen petals), onset of ripening (softening of the pulp and/ or altered fruit skin color), and end of ripening (end of harvest). The data were extracted from field notes collected at experimental orchards (harvest type) of the FEPAGRO Serra (peach, plum, pear, and kiwi cultivars) and the EMBRAPA Uva e Vinho (grape cultivars). The phenological records comprised the following time ranges: 2004-2013 for the Tropic Beauty and Eragil peach trees; 2001-2010 for the Gulf Blaze and Letícia plum trees; 1984-1993 for the Chardonnay and Cabernet Sauvignon grape vines; 1991-2000 for the Smith and Packham's pear trees; and 1997-2006 for the Golden King and Hayward kiwi vines.

\section{Meteorological database}

Daily minimum (Tmin) and maximum air temperature (Tmax) data were recorded by the FEPAGRO Serra meteorological station in Veranópolis, RS, and the EMBRAPA Uva e Vinho meteorological station in Bento Gonçalves, RS, Brazil. The meteorological data comprised a 10-year sampling period (equal period to the phenological data) and the sampling site varied with the fruit species; the meteorological data from the Veranópolis station were used with the pear, peach, plum, and kiwi phenological data, and the meteorological data from the Bento Gonçalves station were used with the grape phenological data. The phenological data could then be related to the meteorological data of the given site and corresponding crop period.

\section{Thermal time (degree-days)}

The following phenological phases for the grape, pear, and kiwi crops were used to calculate degree-days: (1) budburst until onset of flowering; (2) onset of flowering until end of flowering; (3) end of flowering until onset of ripening; (4) onset of ripening until end of ripening; and (5) budburst until end of ripening. Due to flowering preceding budburst for the peach and plum crops, the set of phenological phases analyzed for these had to be modified as follows: (1) from the onset of flowering to budburst; (2) from budburst to end of flowering; and (5) from onset of flowering to end of ripening; phases 3 and 4 were unchanged. The respective intervals were monitored based on the accumulated degree-days, according to the method proposed by Villa Nova et al. (1972).

$$
\begin{gathered}
\mathrm{DD}=(\mathrm{Tmin}-\mathrm{Tb})+(\mathrm{Tmax}-\mathrm{Tmin}) / 2, \\
\text { for } \mathrm{Tmin}>\mathrm{Tb} ; \\
\mathrm{DD}=(\mathrm{Tmax}-\mathrm{Tb})^{2} / 2(\mathrm{Tmax}-\mathrm{Tmin}), \\
\text { for } \mathrm{Tmin}<\mathrm{Tb} ; \\
\mathrm{DD}=0, \text { for } \mathrm{Tb}>\mathrm{Tmax} .
\end{gathered}
$$

where: DD is degree-days; Tmax is daily maximum temperature $\left({ }^{\circ} \mathrm{C}\right)$; $\quad$ Tmin is daily minimum temperature $\left({ }^{\circ} \mathrm{C}\right)$, and $\mathrm{Tb}$ is lower base temperature $\left({ }^{\circ} \mathrm{C}\right)$.

The thermal time necessary for the range of the phenological phases was related to the mean duration of the respective steps, in days, to compare distinct measurements monitored throughout the phenological cycle of the fruit species. 


\section{Statistical analysis}

The data referring to final budburst rate were subjected to analysis of variance. Results that were significantly different according to an F-test were subjected to Tukey's test (5\% probability). The inverse of the 'number of days until budburst' data (1/days until budburst) was inserted into regression curves to define the $\mathrm{Tb}$ of the fruit cultivars. For the variables related to thermal time and days, computed during the phenological phases of the fruit tree cycles, analysis was performed using descriptive statistics for central tendency (mean) and dispersion (coefficient of variation).

\section{Results and Discussion}

\section{Lower Tb of the temperate fruit trees}

Regarding evaluation of $\mathrm{Tb}$ in the temperate fruit cultivars, Figures 1, 2, 3, 4, and 5 show the results for budburst percentage and inverse number of days until budburst when subjected to temperatures of 2 , $4,6,8,10$, and $12^{\circ} \mathrm{C}$, after a prolonged cold period of $1,008 \mathrm{H}_{\mathrm{C}}$ at $0^{\circ} \mathrm{C}$. At the temperatures that induced budburst, success was above $80 \%$ for all of the cultivars (Figures 1A, 1B, 2A, 2B, 3A, 3B, 4A, 4B, $5 \mathrm{~A}$, and $5 \mathrm{~B})$. For the temperatures considered below the threshold of induced bud growth, budburst was null, even after 110 days of exposure. Inverse number of days until budburst (1/days), integrated at the different temperatures, resulted in linear regression graphs for all of the cultivars (Figures 1C, 1D, 2C, $2 \mathrm{D}, 3 \mathrm{C}, 3 \mathrm{D}, 4 \mathrm{C}, 4 \mathrm{D}, 5 \mathrm{C}$, and $5 \mathrm{D}$ ), where $\mathrm{Tb}$ of the genotypes was defined as the intersection of the line with the X-axis. Accordingly, $\mathrm{Tb}$ was obtained using the linear regression equations with inverse number of days until budburst set equal to zero, a method previously described by Putti et al. (2000). That study showed that setting the inverse of the number of days until budburst equal to zero may reveal the starting point from which plants resume their development index.

Natural phenomena applied to a dependent variable with a compact range may be adjusted appropriately to fit a linear function (LAW;
KELTON, 2000). Therefore, linear regression is a good model for fitting to the budburst data obtained in the present study, which had results achieved within a compressed range between 2 and $12^{\circ} \mathrm{C}$. However, such regression should not be extrapolated for use with extreme temperatures (above or below the study's interval), since biological processes usually do not follow linear functions. Biological responses to environmental conditions and the development of phenomena over time itself are typically non-linear. Thus, linear models usually only represent simplifications of biological processes (BONHOMME, 2000).

For the peach cultivars, the budburst percentage obtained at the different temperatures (Figures 1A and $1 \mathrm{~B}$ ) showed that $\mathrm{Tb}$ of the genotypes ranges from 2 to $4^{\circ} \mathrm{C}$ for $\mathrm{EC}-$ Tropic Beauty and ranges from 6 to $8^{\circ} \mathrm{C}$ for LC-Eragil. Because budburst occurred at the higher of these temperatures $\left(4^{\circ}, 8^{\circ} \mathrm{C}\right)$, but not at the lower $\left(2^{\circ}, 6^{\circ} \mathrm{C}\right)$, the $\mathrm{Tb}$ values for these cultivars must be within the ranges indicated. This was confirmed using the linear regression equation: $\mathrm{Tb}$ values of $2.2^{\circ} \mathrm{C}$ and $6.3^{\circ} \mathrm{C}$ were estimated for the cultivars Beauty and Eragil, respectively (Figures $1 \mathrm{C}$ and 1D). For plum, the responses were identical to peach, where $\mathrm{Tb}$ ranges from 2 to $4^{\circ} \mathrm{C}$ for $\mathrm{EC}$ Gulf Blaze and ranges from 6 to $8^{\circ} \mathrm{C}$ for LC-Letícia (Figures $2 \mathrm{~A}$ and $2 \mathrm{~B}$ ). In this case, using the linear regression equation, $\mathrm{Tb}$ values of $2.2^{\circ} \mathrm{C}$ and $6.2^{\circ} \mathrm{C}$ were estimated for the Gulf Blaze and Letícia cultivars, respectively (Figures $2 \mathrm{C}$ and 2D). It is noteworthy that $\mathrm{Tb}$ was lower for the early-season cultivars and higher for the late-season cultivars in these fruit species, which implies a differential trend for this parameter imposed by the fruit cultivars' degree of precocity. The basal temperatures found for the late cultivars of peach and plum, $6.3^{\circ} \mathrm{C}$ and $6.2^{\circ} \mathrm{C}$, respectively, are close to the results obtained by Rodríguez (1995) and Marra et al. (2002), who obtained lower $\mathrm{Tb}$ values between 5 and $7^{\circ} \mathrm{C}$ for intermediate- to late-season stone fruit. However, this contrasts with the work of Richardson et al. (1975), wherein $4.5^{\circ} \mathrm{C}$ is considered an acceptable generic $\mathrm{Tb}$ value for all temperate fruit trees. 
Figure 1. Total budburst (A and B) and linear regressions (C and D) used to define lower $\mathrm{Tb}$ in the peach cultivars Tropic Beauty and Eragil. The buds were subjected to temperatures of 2, 4, 6, 8, 10, and $12^{\circ} \mathrm{C}$ for $110 \mathrm{~d}$, after 1,008 $\mathrm{H}_{\mathrm{C}}$ at $0^{\circ} \mathrm{C}$. Veranópolis, RS, Brazil, 2014. Means followed by the same letter do not differ by Tukey's test at $5 \%$ probability.
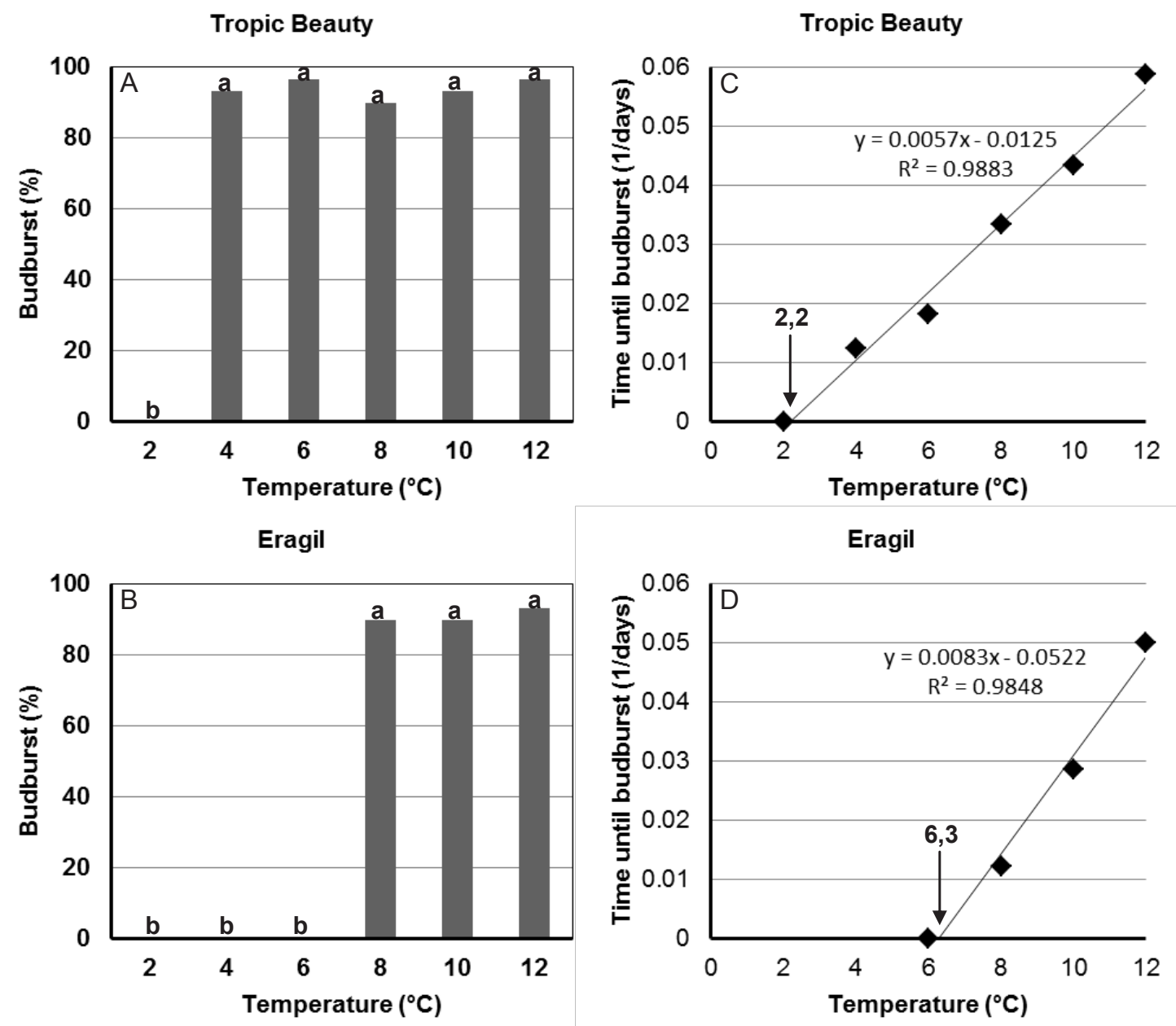
For grape, EC -Chardonnay exhibited lower $\mathrm{Tb}$ between 2 and $4{ }^{\circ} \mathrm{C}$ (Figure 3A). In turn, LC -Cabernet Sauvignon exhibited $\mathrm{Tb}$ between 4 and $6^{\circ} \mathrm{C}$ (Figure 3B). Using the linear regression equation, Chardonnay and Cabernet Sauvignon were found to have minimum basal temperature values of $2.1^{\circ} \mathrm{C}$ and $4.3^{\circ} \mathrm{C}$, respectively (Figures 3C and $3 \mathrm{D}$ ). Similar to the results observed for stone fruit, $\mathrm{Tb}$ values differ between groups of cultivars and are lower for early cultivars than for late cultivars. The $\mathrm{Tb}$ results of $2.1^{\circ} \mathrm{C}$ for Chardonnay and $4.3^{\circ} \mathrm{C}$ for Cabernet Sauvignon contrast with those obtained by Richardson et al. (1975) of $4.5^{\circ} \mathrm{C}$ (especially for EC - Chardonnay) and even more so with those obtained by Hidalgo (1980), Pedro Junior et al. (1994), and Nagata et al. (2000), who define a minimum basal temperature of $10^{\circ} \mathrm{C}$ for grape.

Figure 2. Total budburst (A and B) and linear regressions (C and D) used to define the lower Tb of plum cultivars Gulf Blaze and Letícia. The buds were subjected to temperatures of 2, 4, 6, 8, 10, and $12^{\circ} \mathrm{C}$ for $110 \mathrm{~d}$, after $1,008 \mathrm{H}_{\mathrm{C}}$ at $0^{\circ} \mathrm{C}$. Veranópolis, RS, Brazil, 2014. Means followed by the same letter do not differ by Tukey's test at $5 \%$ probability.
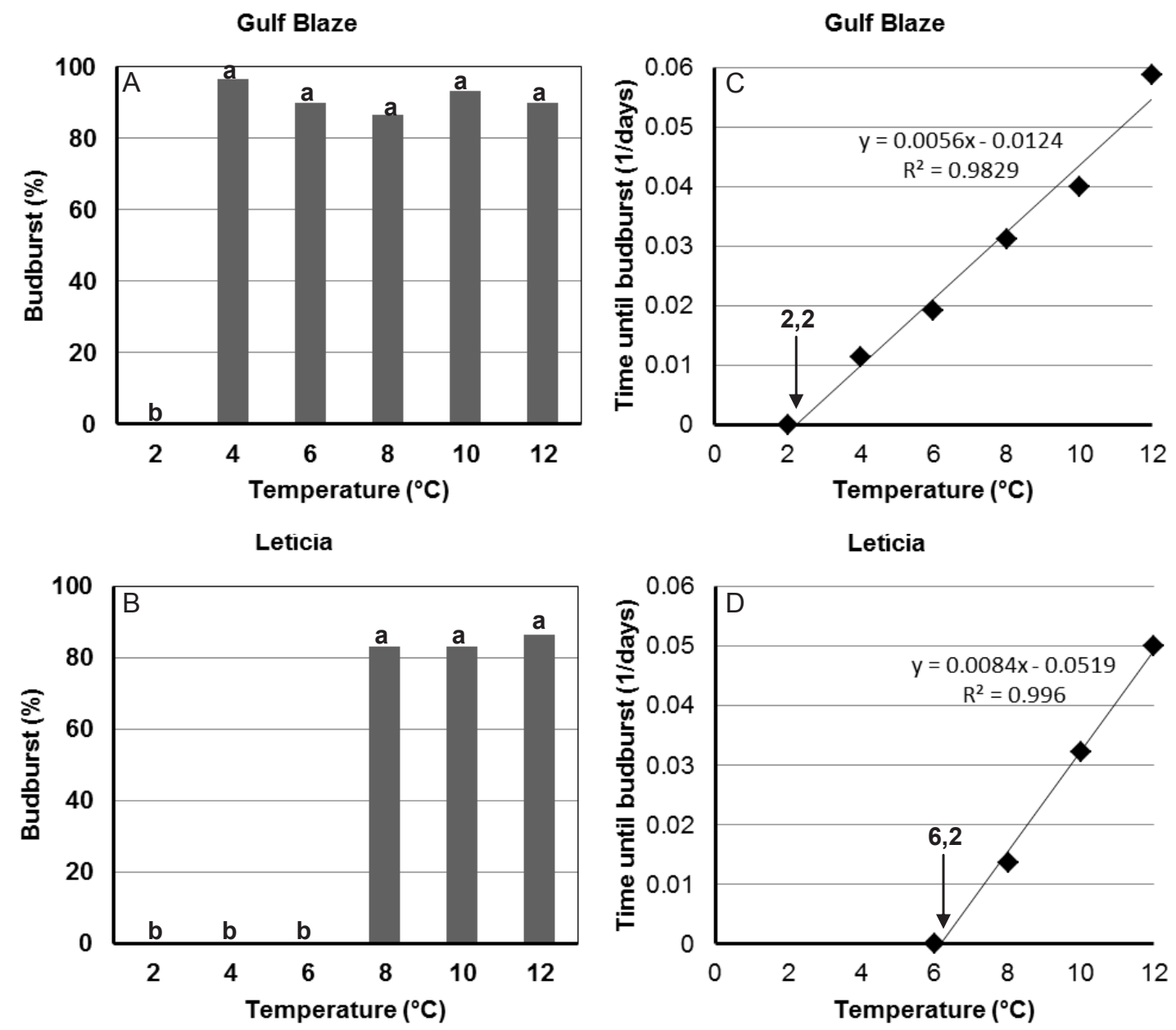
Figure 3. Total budburst ( $\mathrm{A}$ and $\mathrm{B}$ ) and linear regressions ( $\mathrm{C}$ and $\mathrm{D}$ ) used to define the lower Tb of the grape cultivars Chardonnay and Cabernet Sauvignon. The buds were subjected to temperatures of 2, 4, 6, 8, 10, and $12^{\circ} \mathrm{C}$ for $110 \mathrm{~d}$, after $1,008 \mathrm{H}_{\mathrm{C}}$ at $0^{\circ} \mathrm{C}$. Veranópolis, RS, Brazil, 2014. Means followed by the same letter do not differ by Tukey’s test at $5 \%$ probability.

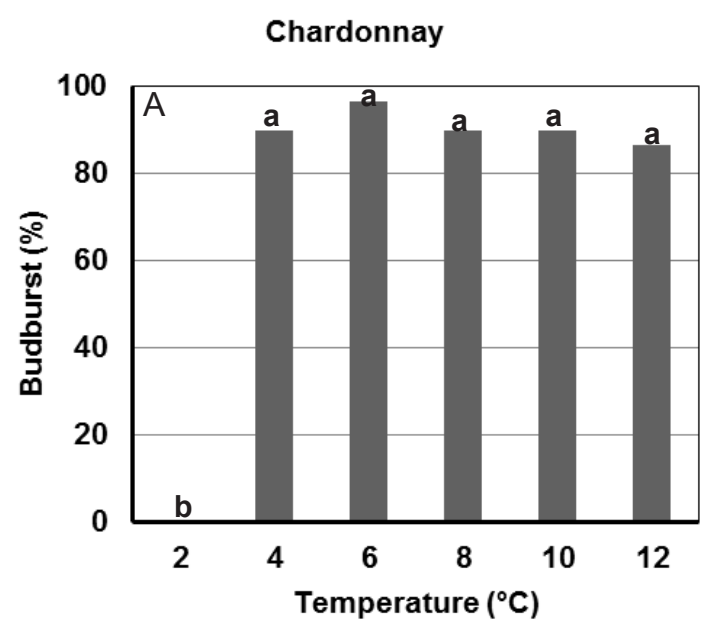

Cabernet Sauvignon

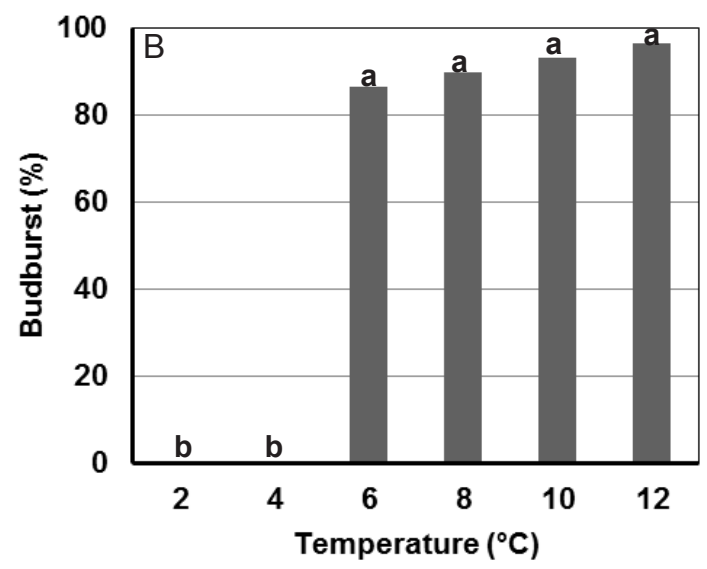

The responses were similar at the different temperatures tested for the pear and kiwi cultivars (Figures 4 and 5). The $\mathrm{Tb}$ value was within the 4 to $6^{\circ} \mathrm{C}$ range for the early cultivars (Smith pear and Golden King kiwi) (Figures 4A and 5A). Tb remained between 8 and $10^{\circ} \mathrm{C}$ for the late cultivars (Packham's pear and Hayward kiwi) (Figures 4B and $5 \mathrm{~B})$. Using the linear regression equation, Tb was $4.4^{\circ} \mathrm{C}$ and $4.3^{\circ} \mathrm{C}$ for the Smith pear and Golden King kiwi cultivars, respectively (Figures $4 \mathrm{C}$ and $5 \mathrm{C}$ ). For the late cultivars, $\mathrm{Tb}$ was $8.2^{\circ} \mathrm{C}$ for Packham's pear and Hayward kiwi (Figures 4D and 5D). As noted for the other crops, both species showed a difference in the $\mathrm{Tb}$ parameter consistent

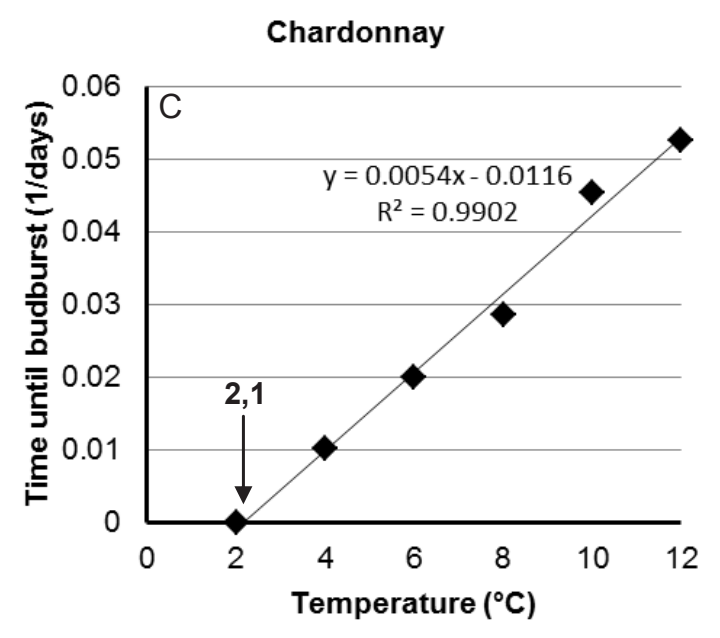

Cabernet Sauvignon

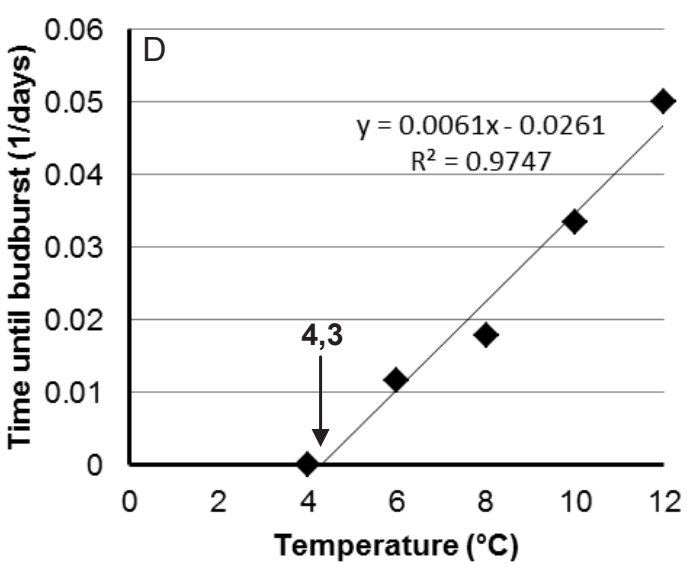

with the genotype's precocity. For the pear tree Pyrus communis, Spiegel-Roy and Alston (1979) defined $4.5^{\circ} \mathrm{C}$ as the basal temperature for the crop's growth, close to that found for the Smith early cultivar in this study and equal to that suggested by Richardson et al. (1975). For kiwi, Morley-Bunker and Salinger (1987) estimated $7.5^{\circ} \mathrm{C}$ as the basal minimum temperature and Green (2007) defined $10^{\circ} \mathrm{C}$ as the temperature below which the crop's growth is negligible or null; these values are within the range obtained for the Hayward kiwi late cultivar in this study, but contrast with the reference value of $4.5^{\circ} \mathrm{C}$ proposed by Richardson et al. (1975). 
Figure 4. Total budburst ( $\mathrm{A}$ and $\mathrm{B}$ ) and linear regressions (C and $\mathrm{D})$ used to define the lower $\mathrm{Tb}$ of the pear cultivars Smith and Packham's. The buds were subjected to temperatures of 2, 4, 6, 8, 10, and $12^{\circ} \mathrm{C}$ for $110 \mathrm{~d}$, after $1,008 \mathrm{H}_{\mathrm{C}}$ at $0^{\circ} \mathrm{C}$. Veranópolis, RS, Brazil, 2014. Means followed by the same letter do not differ by Tukey's test at 5\% probability.
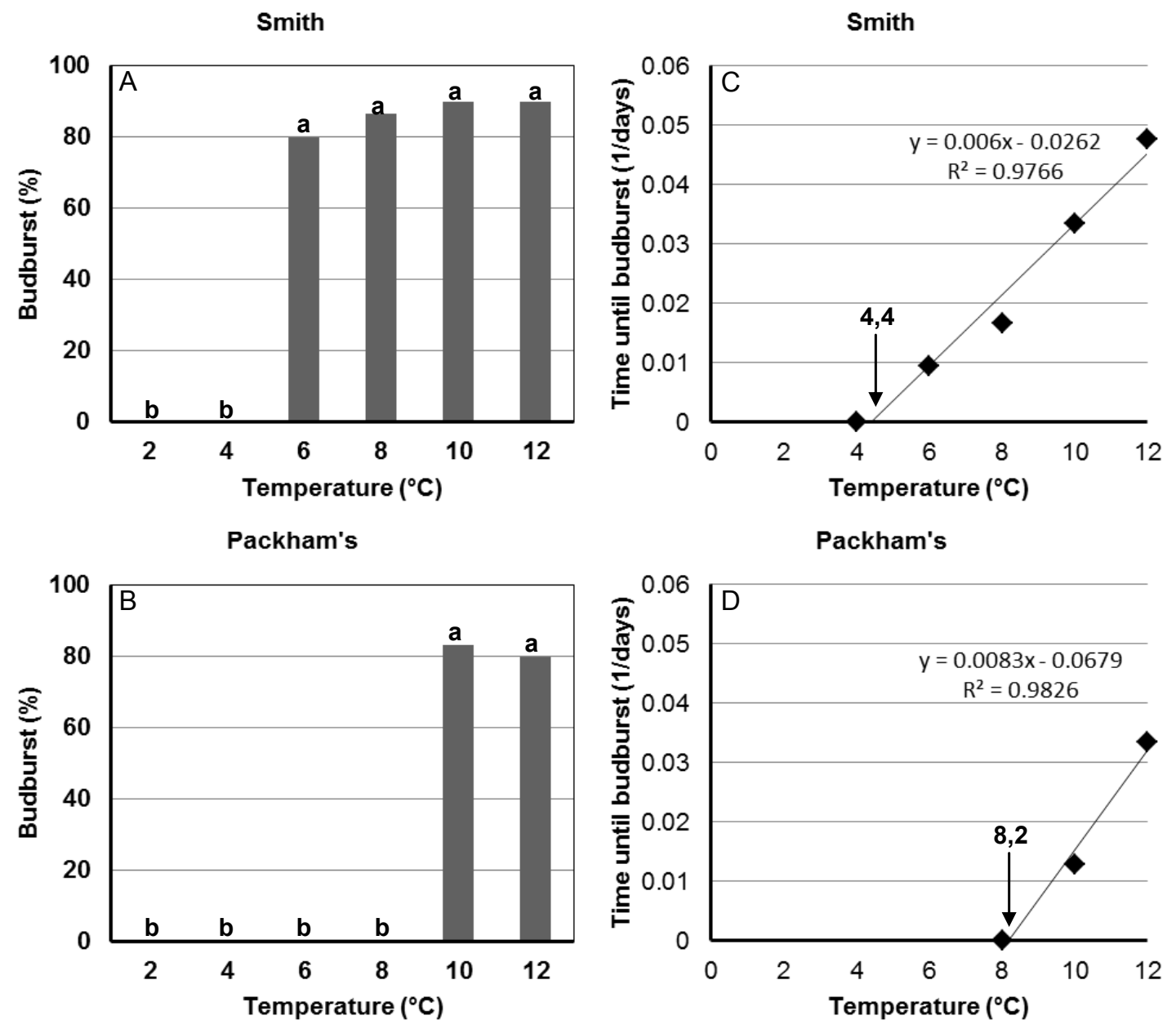

The present study highlights many instances of $\mathrm{Tb}$ differing among fruit species, confirming the inexistence of a single lower thermal threshold for temperate fruit tree growth, supporting the inadvisability of the generic $4.5^{\circ} \mathrm{C} \mathrm{Tb}$ standard so extensively employed for temperate fruit trees (RICHARDSON et al., 1975; BERGAMASCHI, differentiating the $\mathrm{Tb}$ data by the genotypes' precocity illustrates differences never previously considered in the scientific literature. Thus, we propose a classification system of effective temperature rating of heat based on different groups of cultivars (early, intermediate, and late), rather than a single value per crop. 2007; CARDOSO et al., 2012). Additionally, 
Figure 5. Total budburst (A and B) and linear regressions (C and D) used to define the lower Tb of the kiwi cultivars Golden King and Hayward. The buds were subjected to temperatures of $2,4,6,8,10$, and $12^{\circ} \mathrm{C}$ for $110 \mathrm{~d}$, after 1,008 $\mathrm{H}_{\mathrm{C}}$ at $0^{\circ} \mathrm{C}$. Veranópolis, RS, Brazil, 2014. Means followed by the same letter do not differ by Tukey's test at $5 \%$ probability.
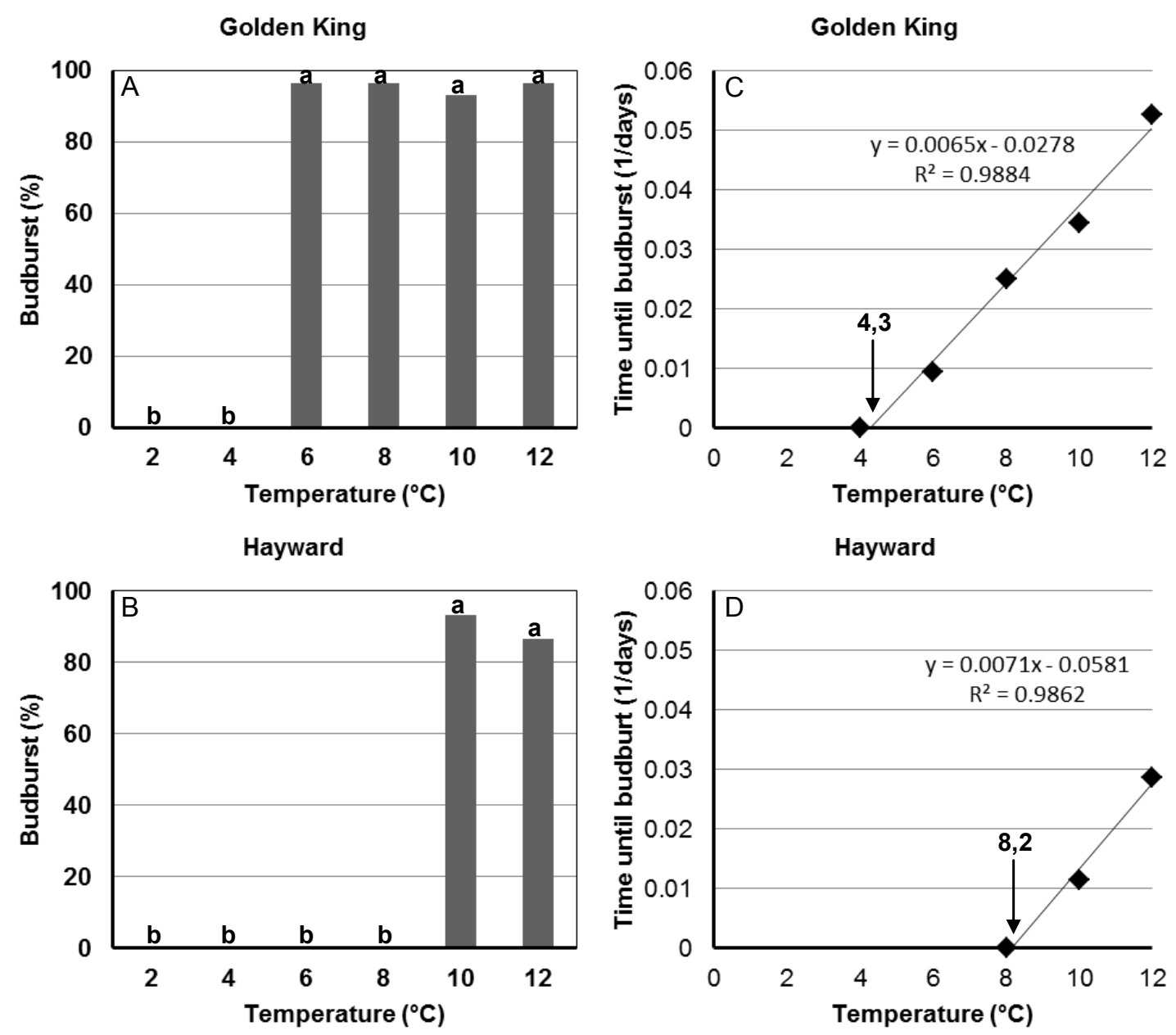

As discussed previously, early cultivars have lower basal temperatures compared to late cultivars, regardless of the fruit species. Thus, the heat computation mechanism for vegetative development differs among genotypes. These results are important as support for modeling studies; prediction of growth stages will be improved by considering different heat accumulation rates above a temperature threshold, varying with genotype precocity. Other examples in the literature validate this observation. Degrandi-Hoffman et al. (1996) show that almond cultivars that bloom early tend to exhibit lower basal temperatures than those that

bloom later. Gianfagna and Mehlenbacher (1985) show that late apple tree clones are less responsive to a temperature of $10^{\circ} \mathrm{C}$ for growth than early clones, suggesting that the basal temperature can be higher in genotypes that bloom later. Scarpare (2007) states that the Tb may vary for each fruit tree species and/or cultivar, and that it may also vary with the plants' phenological phase, though it is common to adopt a mean value for the crop's entire growing season because it is easier to do so.

Hawerroth et al. (2010) demonstrate that the use of laboratory methods is essential to enable 
isolated testing of environmental factors. Under field conditions, with restrictions on what can be controlled (e.g., radiation, rainfall, and temperature), it was not possible to precisely determine $\mathrm{Tb}$ of the fruit species, due to the complexity of interactions between the environment and the plant. By taking data from a biological test conducted under controlled conditions, we were able to obtain the results presented in Figures 1 to 5, which faithfully represent the responses of the plants to the air temperature variable, isolated from other factors. The results contrast those described by Richardson et al. (1975); Spiegel-Roy and Alston (1979); Hidalgo (1980); Morley-Bunker and Salinger (1987); Pedro
Junior et al. (1994); Rodríguez (1995); Nagata et al. (2000); Marra et al. (2002); Green (2007); and Souza et al. (2011b), who determined Tb by simulation only using the statistical modeling proposed by Arnold (1959).

Other contributions of the study are shown in Table 1. The $\mathrm{Tb}$ of the temperate fruit cultivars is directly related to the genotypes' chilling requirements during dormancy. The higher the winter chilling requirement, the higher the cultivars' Tb was. An innovative character of these results is the division of genotypes by chilling requirement contrasted with their rate of degree-day accumulation for plant growth.

Table 1. Relationship between chilling hours $\leq 7.2^{\circ} \mathrm{C}$ and lower $\mathrm{Tb}$ for different temperate fruit cultivars. Veranópolis, Brazil, 2014.

\begin{tabular}{cccc}
\hline Crop & Cultivar & Chilling hours $\leq \mathbf{7 . 2} \mathbf{~}^{\circ} \mathbf{C}(\mathbf{h})$ & $\mathbf{T b}$ \\
\hline Grape & Chardonnay & 150 & 2.1 \\
Peach & Tropic Beauty & 150 & 2.2 \\
Plum & Gulf Blaze & 200 & 2.2 \\
Kiwi & Golden King & 300 & 4.3 \\
Pear & Smith & 400 & 4.4 \\
Grape & Cabernet Sauvignon & 450 & 4.3 \\
Peach & Eragil & 550 & 6.3 \\
Plum & Letícia & 600 & 6.2 \\
Pear & Packham's & 840 & 8.2 \\
Kiwi & Hayward & 1000 & 8.2 \\
\hline
\end{tabular}

Estimated phenology of the temperate fruit trees based on accumulated degree-days

The phenological records from the 10-year series show the different precocity among the fruit cultivars (Table 2). The early cultivars start their growing seasons earlier by budburst and/or flowering, and end correspondingly earlier compared to the late cultivars for all the crops.

The thermal time, in degree-days, was approximated for each phenological phase within a single crop, independent of the cultivars' degree of precocity (Table 3 ). From the phenological phase between the onset of the growing season and end of ripening, i.e., from the onset of flowering to the end of ripening for stone fruit, and from budburst to the end of ripening for the other species, we calculated total degree-day sums. For peach, the total degreedays were 1720.9 for Tropic Beauty and 1801.5 for Eragil; for plum, 1680.3 for Gulf Blaze and 1718.4 for Letícia; for grape, 2310.0 for Chardonnay and 2369.6 for Cabernet Sauvignon; for pear, 2096.4 for Smith and 2003.1 for Packham's; and for kiwi, 2775.0 for Golden King and 2691.9 for Hayward (Table 3). 
Table 2. Mean phenological dates (Day/Month format) of cultivars of peach (Tropic Beauty and Eragil), plum (Gulf Blaze and Letícia), grape (Chardonnay and Cabernet Sauvignon), pear (Smith and Packham's), and kiwi (Golden King and Hayward), considering a 10-year evaluation period, in experimental orchards at FEPAGRO Serra, Veranópolis, RS, and the Embrapa Uva e Vinho, Bento Gonçalves, RS, Brazil.

\begin{tabular}{cccccccc}
\hline Crop & Cultivar & Year & B & OF & EF & OR & ER \\
\hline \multirow{2}{*}{ Peach } & Tropic Beauty & $2004-2013$ & $14 / 07$ & $04 / 07$ & $30 / 07$ & $20 / 10$ & $06 / 11$ \\
& Eragil & $2004-2013$ & $29 / 08$ & $17 / 08$ & $21 / 09$ & $11 / 01$ & $31 / 01$ \\
\hline \multirow{2}{*}{ Plum } & Gulf Blaze & $2001-2010$ & $21 / 07$ & $09 / 07$ & $11 / 08$ & $28 / 10$ & $19 / 11$ \\
& Letícia & $2001-2010$ & $21 / 09$ & $13 / 09$ & $09 / 10$ & $14 / 01$ & $28 / 01$ \\
\hline \multirow{2}{*}{ Grape } & Chardonnay & $1984-1993$ & $08 / 09$ & $16 / 10$ & $02 / 11$ & $22 / 12$ & $23 / 01$ \\
& Cab.Sauvign. & $1984-1993$ & $02 / 10$ & $02 / 11$ & $19 / 11$ & $08 / 01$ & $17 / 02$ \\
\hline \multirow{2}{*}{ Pear } & Smith & $1991-2000$ & $12 / 08$ & $18 / 08$ & $15 / 09$ & $08 / 01$ & $19 / 01$ \\
& Packham's & $1991-2000$ & $05 / 09$ & $15 / 09$ & $06 / 10$ & $28 / 01$ & $11 / 02$ \\
\hline \multirow{2}{*}{ Kiwi } & Golden King & $1997-2006$ & $11 / 09$ & $06 / 10$ & $30 / 10$ & $14 / 03$ & $24 / 03$ \\
& Hayward & $1997-2006$ & $26 / 09$ & $03 / 11$ & $18 / 11$ & $27 / 04$ & $15 / 05$ \\
\hline \multirow{2}{*}{. }
\end{tabular}

(*) B - budburst; OF - onset of flowering; EF - end of flowering; OR - onset of ripening; ER - end of ripening.

The thermal time, in degree-days, is similar among cultivars belonging to the same crop. This is most probably explained by the difference in $\mathrm{Tb}$ found for each genotype and its relationship to the mean air temperature and duration of the plants' growing seasons. Late cultivars, because they have higher $\mathrm{Tb}$, accumulate fewer degree-days and are similar to the early cultivars in thermal time at different phenological phases-the longer and/or warmer period during their phenological intervals. Thus, based on the results obtained it is possible to conclude that cultivars of the same fruit species exhibit an almost equal thermal time during the growing season, overall differing by the $\mathrm{Tb}$ that regulates and/or triggers their growth. Comparative studies among fruit cultivars and species, with $\mathrm{Tb}$ defined by controlled biological methods and combined with extensive phenological and meteorological series, are not yet reported in the scientific literature, which highlights the importance of the results of this study for understanding and characterizing the phenology of fruit trees.

In comparing calendar days versus thermal time (degree-days) for the phenological phases of the cultivars studied, thermal time (degree-days) conferred a lower coefficient of variation in $82 \%$ of cases compared to the calendar days (Table 3 ). The reduced variability observed in the analysis of the 10 -year time series reinforces the hypothesis that plant phenology relies more on "thermal time" (degree-days) than on chronological time (days) for monitoring the growing season.

According to Bergamaschi (2007), using the number of calendar days as the independent variable, instead of a thermal time criterion (i.e., degree-days), restricts the validity of simulation models to similar environments to those where the data were generated. There will always be discrepancies in estimates for such models when used at sites or during seasons with different thermal conditions. According to Cardoso et al. (2012), using the degree-day sum based on accumulated energy above a certain $\mathrm{Tb}$ has comprehensive use in simulating phenological development and plant growth. Although water and photoperiod can also affect plant phenology, in most crops, the thermal time has a direct relationship with plant development (MILLER et al., 2001). Predicting critical periods, ecoclimatic demand of the crops, establishing important management practices, and using modeling in agroclimatic zoning are some examples of applying degree-days to agricultural crops (DAY et al., 2008). According to Souza et al. (2011a), degree-day sum allows for precisely estimating growing season duration and occurrence of important phases or events throughout the phenological development of the plants, as shown in Table 3. 
Table 3. Mean thermal time, in degree-days (DD), and mean duration, in days, of the phenological phases of the growing season of cultivars of peach (Tropic Beauty and Eragil), plum (Gulf Blaze and Letícia), grape (Chardonnay and Cabernet Sauvignon), pear (Smith and Packham's), and kiwi (Golden King and Hayward), over a 10-year evaluation period.

\begin{tabular}{|c|c|c|c|c|c|c|c|c|c|c|c|}
\hline \multirow{2}{*}{$\stackrel{0}{0}$} & \multirow{2}{*}{ 离 } & \multicolumn{2}{|c|}{ OF - B* } & \multicolumn{2}{|c|}{$\mathbf{B}-\mathbf{E F}$} & \multicolumn{2}{|c|}{ EF-OR } & \multicolumn{2}{|c|}{ OR - ER } & \multicolumn{2}{|c|}{ OF - ER } \\
\hline & & Days & DD & Days & DD & Days & DD & Days & DD & Days & DD \\
\hline \multirow{4}{*}{ 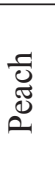 } & Tropic Beauty & 8.1 & 90.1 & 21.4 & 248.2 & 81.8 & 1112.0 & 17.5 & 270.6 & 128.9 & 1720.9 \\
\hline & $\mathrm{CV}(\%)^{* *}$ & 22.8 & 20.6 & 25.5 & 22.9 & 9.4 & 8.5 & 13.5 & 11.2 & 7.0 & 7.5 \\
\hline & Eragil & 14.1 & 105.9 & 22.8 & 217.0 & 114.5 & 1226.1 & 17.5 & 252.5 & 168.9 & 1801.5 \\
\hline & $\mathrm{CV}(\%)$ & 27.1 & 19.5 & 16.5 & 21.0 & 4.1 & 3.9 & 19.8 & 13.5 & 6.1 & 5.0 \\
\hline \multirow{4}{*}{$\frac{\Xi}{Q}$} & Gulf Blaze & 12.0 & 131.9 & 20.2 & 232.6 & 82.0 & 1057.2 & 17.3 & 258.6 & 131.5 & 1680.3 \\
\hline & CV $(\%)$ & 23.2 & 12.6 & 30.4 & 14.8 & 7.4 & 7.0 & 14.4 & 9.9 & 5.5 & 4.9 \\
\hline & Letícia & 14.3 & 137.2 & 18.1 & 190.3 & 96.6 & 1163.5 & 13.9 & 227.4 & 142.9 & 1718.4 \\
\hline & CV (\%) & 22.9 & 27.4 & 14.6 & 11.5 & 5.6 & 5.2 & 19.0 & 9.3 & 2.9 & 3.8 \\
\hline \multirow{2}{*}{$\stackrel{0}{0}$} & \multirow{2}{*}{ U. } & \multicolumn{2}{|c|}{$\mathbf{B}-\mathbf{O F}$} & \multicolumn{2}{|c|}{$\mathbf{O F}-\mathbf{E F}$} & \multicolumn{2}{|c|}{ EF - OR } & \multicolumn{2}{|c|}{$\mathbf{O R}-\mathbf{E R}$} & \multicolumn{2}{|c|}{$\mathbf{B}-\mathbf{E R}$} \\
\hline & & Days & DD & Days & DD & Days & DD & Days & DD & Days & DD \\
\hline \multirow{4}{*}{ 芯 } & Chardonnay & 37.5 & 447.7 & 17.4 & 250.1 & 50.2 & 919.5 & 31.8 & 692.7 & 136.9 & 2310.0 \\
\hline & CV $(\%)$ & 21.9 & 7.0 & 25.0 & 11.3 & 7.4 & 7.2 & 14.3 & 11.8 & 5.8 & 4.1 \\
\hline & $\begin{array}{c}\text { Cab. } \\
\text { Sauvionon }\end{array}$ & 33.1 & 443.8 & 17.1 & 246.4 & 50.4 & 879.7 & 45.5 & 799.7 & 146.1 & 2369.6 \\
\hline & CV $(\%)$ & 37.4 & 12.7 & 28.3 & 15.3 & 8.5 & 3.1 & 13.8 & 7.0 & 9.2 & 2.7 \\
\hline \multirow{4}{*}{$\stackrel{\bar{\varpi}}{2}$} & Smith & 6.1 & 58.7 & 28.5 & 259.6 & 112.3 & 1577.8 & 11.7 & 200.3 & 158.6 & 2096.4 \\
\hline & CV $(\%)$ & 19.6 & 17.1 & 20.0 & 6.2 & 7.6 & 5.9 & 14.0 & 17.1 & 7.1 & 4.2 \\
\hline & Packham's & 9.6 & 72.3 & 20.8 & 202.6 & 115.2 & 1526.3 & 13.8 & 201.9 & 159.4 & 2003.1 \\
\hline & CV (\%) & 16.4 & 8.6 & 15.3 & 14.7 & 5.4 & 6.3 & 12.2 & 10.7 & 5.2 & 5.7 \\
\hline \multirow{4}{*}{ 结 } & Golden King & 25.5 & 283.0 & 23.4 & 229.1 & 135.4 & 2132.9 & 10.0 & 130.0 & 194.3 & 2775.0 \\
\hline & CV $(\%)$ & 23.6 & 19.6 & 25.4 & 20.5 & 6.7 & 5.1 & 8.2 & 13.0 & 3.2 & 3.0 \\
\hline & Hayward & 40.5 & 315.5 & 15.4 & 171.0 & 159.5 & 2059.3 & 18.0 & 146.1 & 233.4 & 2691.9 \\
\hline & CV (\%) & 15.2 & 9.9 & 11.9 & 11.7 & 4.8 & 4.6 & 14.6 & 19.3 & 3.1 & 2.9 \\
\hline
\end{tabular}

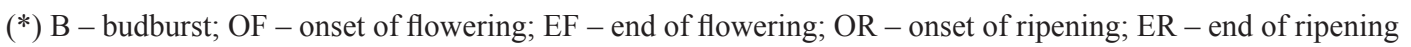

$(* *) \mathrm{CV}-$ coefficient of variation.

Classifying genotypes by precocity, using names such as early, intermediate, and late, is inaccurate for large-scale use (BERGAMASCHI, 2007). Precocity depends on genetic traits; however the genotypeenvironment interactions always change when the environmental conditions change, so precocity classification is only valid for certain conditions of each environment. For this reason, the growth cycle of each genotype should be characterized according to its particularities regarding thermal requirements, but this does not always occur. According to Berlato and Sutili (1976), degree-day estimates should consider the differences in the cardinal temperatures between groups based on maturation or precocity, which have varying rates according to genotype. The differentiation in $\mathrm{Tb}$ and the equal thermal time observed between different cycles for each crop (Table 3) meets the proposition suggested and is an important point in the evolution of understanding phenology and the climate-plant relationship in fruit tree species.

Characterizing the $\mathrm{Tb}$ and estimating phenology from accumulated thermal time are important for 
facing climate change scenarios. Global warming tends to elevate the air temperature and cause changes in accumulated degree-days, and consequently, changes the date at which phenological steps occur (LEGAVE et al., 2008). Overall, an advance of the growing season is expected due to crops accumulating more daily thermal time above the $\mathrm{Tb}$, by elevation in the mean air temperature. This work, with its definition of Tb by genotype, may be used to predict changes in phenological patterns caused by climate change, and even predict their agronomic implications. According to the IPCC (2007), there are three possible warming scenarios that could occur for southern Brazil by the end of the $21 \mathrm{st}$ century: increases in minimum of $1^{\circ} \mathrm{C}, 3^{\circ} \mathrm{C}$, or $5.8^{\circ} \mathrm{C}$. Any of these would result in altered phenological behavior of fruit trees, with greater or lesser intensity depending on the future climate scenario.

\section{Conclusions}

Lower $\mathrm{Tb}$ differs among temperate fruit tree species.

Lower $\mathrm{Tb}$ is lower for early cultivars and higher for late cultivars in peach, plum, grape, pear, and kiwi crops.

Lower $\mathrm{Tb}$ of a temperate fruit cultivar is conditioned by the genotype's chilling requirements, where the higher the winter chilling requirement, the higher the cultivar's Tb.

Cultivars belonging to the same fruit species exhibit almost equal thermal time at the end of the growing season, regardless of degree of precocity or maturation of the genotype.

Differentiation of the lower $\mathrm{Tb}$ between genotypes is an important factor to be considered for fitting phenological models, as it is fundamental to improving their precision and applicability in agriculture.

\section{References}

ANZANELLO, R. Fisiologia e modelagem da dormência de gemas em macieira. 2012. Tese (Doutorado em Fitotecnia - Fisiologia e Manejo Vegetal) - Faculdade de Agronomia, Universidade Federal do Rio Grande do Sul, Porto Alegre.

ANZANELLO, R.; FIALHO, F. B.; SANTOS, H. P.; MARODIN, G. A. B.; BERGAMASCHI, H. Métodos biológicos para avaliação da brotação de gemas em macieira para modelagem da dormência. Semina: Ciências Agrárias, Curitiba, v. 35, n. 3, p. 1163-1176, 2014.

ARNOLD, C. Y. The determination and significance of the base temperature in a linear heat unit system. Journal of the American Society for Horticultural Science, Geneva, v. 74, n. 1, p. 430-445, 1959.

BERGAMASCHI, H. O clima como fator determinante da fenologia das plantas. In: REGO, G. M.; NEGRELLE, R. R. B.; MORELATTO, L. P. C. (Org.). Fenologia ferramenta para conservação, melhoramento e manejo de recursos vegetais arbóreos. Colombo: EMBRAPA Florestas, 2007. v. 1, p. 291-310.

BERLATO, M. A.; SUTILI, V. R. Determinação das temperaturas-base dos subperíodos emergênciapendoamento e emergência-espigamento de três cultivares de milho (Zea mays L.). In: REUNIÃO TÉCNICA DO MILHO E SORGO, 11., 1976, Piracicaba, SP. Anais... Piracicaba: Departamento de Genética da Escola Superior de Agricultura Luiz de Queiroz, 1976. p. 523-527.

BONHOMME, R. Bases and limits to using degree. day units. European Journal of Agronomy, Berlin, v. 13, n. 1, p. 1-10, 2000.

CARDOSO, L. S.; BERGAMASCHI, H.; BOSCO, L. C.; PAULA, V. A.; MARODIN, G. A. B.; CASAMALI, B.; NACHTIGALL, G. R. Disponibilidades climáticas para macieira na região de Vacaria, RS. Ciência Rural, Santa Maria, v. 42, n. 11, p. 1960-1967, 2012.

CARVALHO, R. I. N.; BIASI, L. A. Índice para a avaliação da intensidade de dormência de gemas de fruteiras de clima temperado. Revista Brasileira de Fruticultura, Jaboticabal, v. 34, n. 3, p. 936-940, 2012.

CARVALHO, R. I. N.; BIASI, L. A.; ZANETTE, F.; SANTOS, J. M.; PEREIRA, G. P. Estádios de brotação de gemas de fruteiras de clima temperado para o teste biológico de avaliação de dormência. Revista Acadêmica de Ciências Agrárias e Ambientais, Curitiba, v. 8, n. 1, p. 93-100, 2010.

DAY, K.; LOPEZ, G.; DEJONG, T. Using growing degree hours accumulated thirty days after bloom to predict peach and nectarine harvest date. Acta Horticulturae, The Hague, v. 803, n. 1, p. 163-166, 2008.

DEGRANDI-HOFFMAN, G.; THORP, R.; LOPER, G.; EISIKOWITCH, D. Describing the progression of 
almond using accumulated heat units. Journal of Applied Ecology, Oxford, v. 33, n. 4, p. 812-818, 1996.

GIANFAGNA, T. J.; MEHLENBACHER, S. A. Importance of heat requirement for bud break and time of flowering in apple. Hortscience, Alexandria, v. 20, n. 1, p. 909-911, 1985.

GREEN, S. R. Kiwifruit dry matter platform: exploiting water stress using summer deficit irrigation. HortResearch, Lincoln, v. 36, n. 3, p. 1-2, 2007.

HAWERROTH, F. J.; HERTER, F. G.; PETRI, J. L.; LEITE, G. B.; PEREIRA, J. F. M. Dormência em frutíferas de clima temperado. Pelotas: Embrapa Clima Temperado, 2010. 56 p. (Documentos, 310).

HIDALGO, L. Caracterización microfisica del ecosistema médio-planta em los viñedos españoles. Madrid: Instituto Nacional de Investigaciones Agrárias, 1980. $255 \mathrm{p}$.

INTERGOVERNMENTAL PANEL ON CLIMATE CHANGE - IPCC. Climate change 2007: the physical science. Cambridge: Cambridge University Press, 2007. $996 \mathrm{p}$.

LAW, M. L.; KELTON, W. D. Simulation modeling and analysis. $3^{\text {th }}$ ed. New York: McGraw-Hill, 2000. 759 p.

LAZZARI, M. Clima e fenologia de cultivares de pessegueiro (Prunus persica) na região do Alto e Médio Vale do Uruguai, RS. 2011. Tese (Doutorado em Fitotecnia) - Faculdade de Agronomia, Universidade Federal do Rio Grande do Sul, Porto Alegre.

LEGAVE, J. M.; FARRERA, I.; ALMERAS, T.; SANTAMARIA, P.; CALLEJA, M. Selecting models of apple flowering time and understanding how global warming has had an impact on this trait. Journal of Horticultural Science and Biotechnology, Ashford, v. 83, n. 1, p. 76-84, 2008.

MARRA, F. P.; INGLESE, P.; CALABRIA, R.; DEJONG, T. M.; JOHNSON, R. S. Thermal time requirement and harvest time forecast for peach cultivars with different fruit development periods. Acta Horticulturae, The Hague, v. 592, n. 1, p. 523-529, 2002.

MILLER, P.; LANIER, W.; BRANDT, S. Using growing degree days to predict plant stages. Bozeman: State University Montana, Extension Service, 2001. 8 p.

MORLEY-BUNKER, M. J.; SALINGER, M. J. Kiwifruit development: the effect of temperature on bud burst and flowering. Weather and Climate, Wellington, v. 7, n. 1, p. 26-30, 1987.

NAGATA, R. K.; SCARPARE FILHO, J. A.; KLUGE, R. A.; NOVA, N. A. V. Tb e soma térmica (graus-dia) para videiras Brasil e Benitaka. Revista Brasileira de Fruticultura, Cruz das Almas, v. 22, n. 3, p. 329-333, 2000.
PEDRO JUNIOR, M. J.; SENTELHAS, P. C.; POMMER, C. V.; MARTINS, F. P. Determinação da Tb, graus-dia e índice biometeorológico para a videira Niagara Rosada. Revista Brasileira de Agrometeorologia, Santa Maria, v. 2, n. 1, p. 51-56, 1994.

PUTTI, G. L.; MENDEZ, M. E. G.; PETRI, J. L. Unidades de frio e de calor para a brotação de macieira (Malus domestica), Gala e Fuji. Revista Brasileira de Agrociência, Pelotas, v. 6, n. 3, p. 194-196, 2000.

PUTTI, G. L.; PETRI, J. L.; MENDEZ, M. E. Temperaturas efetivas para a dormência da macieira. Revista Brasileira de Fruticultura, Jaboticabal, v. 25, n. 2, p. 210-212, 2003.

RICHARDSON, E. A.; SEELEY, S. D.; WALKER, D. R.; ANDERSON, J. L. M.; ASHCROFT, G. L. Phenoclimatography of spring peach bud development. Hortscience, Alexandria, v. 10, n. 3, p. 236-237, 1975.

RODRÍGUEZ, A. R. Multiple regression models for the analysis of potential cultivation areas for Japanese plums. Hortscience, Alexandria, v. 30, n. 3, p. 605-610, 1995.

SCARPARE, F. V. Determinação de índices biometeorológicos da videira Niagara Rosada (Vitis labrusca L.) podada em diferentes épocas e fases do ciclo vegetativo. 2007. Dissertação (Mestrado em Agronomia) - Faculdade de Agronomia, Escola Superior de Agricultura Luiz de Queiroz, Piracicaba.

SCHWARTZ, M. D. Phenology: an integrative environmental science. Hardcover: Tasks for Vegetation Science, 2003. 592 p.

SOUZA, A. P. de; LEONEL, S.; SILVA, A. C. Basal temperature and thermal time in phonological phases of nectarine and peach cultivars. Pesquisa Agropecuária Brasileira, Brasília, v. 46, n. 12, p. 1588-1596, 2011 b.

SOUZA, A. P. de; RAMOS, C. M. C.; LIMA, A. D. de; FLORENTINO, H. O.; ESCOBEDO, J. F. Comparison of methodologies for degree-day estimation using numerical methods. Acta Scientiarum Agronomy, Maringá, v. 33, n. 3, p. 391-400, $2011 \mathrm{a}$.

SPIEGEL-ROY, P.; ALSTON, F. M. Chilling and postdormant heat requirement as selection criteria for late flowering pears. Journal of the American Society for Horticultural Science, Ashford, v. 54, n. 2, p. 115-120, 1979.

VILLA NOVA, N. A.; PEDRO JÚNIOR, M. J.; PEREIRA, A. R.; OMETTO, J. C. Estimativa de grausdia acumulados acima de qualquer $\mathrm{Tb}$ em função das temperaturas máxima e mínima. Ciência da Terra, São Paulo, v. 30, n. 1, p. 1-8, 1972. 